\title{
Yeast Rad55 and Rad57 proteins form a heterodimer that functions with replication protein A to promote DNA strand exchange by Rad51 recombinase
}

\author{
Patrick Sung ${ }^{1}$ \\ Sealy Center for Molecular Science, University of Texas Medical Branch at Galveston, Galveston, Texas 77555-1061 USA
}

\begin{abstract}
Saccharomyces cerevisiae RAD51, RAD55, and RAD57 genes, required for genetic recombination and DNA double-strand-break repair, encode proteins homologous to one another and to the Escherichia coli RecA protein. Rad51 protein catalyzes the DNA strand-exchange reaction with a dependence on ATP and on the heterotrimeric single-strand DNA (ssDNA) binding factor replication protein A (RPA). By several independent criteria, RAD55- and RAD57-encoded products are shown here to exist as a stable heterodimer, with a dissociation constant of $<2 \times 10^{-10} \mathrm{M}$. In strand exchange, the reaction proceeds efficiently if RPA is incorporated after nucleation of Rad51 onto ssDNA, but if RPA is present during the nucleation phase, as is likely the case in vivo, the amount of strand-exchange products becomes relatively insignificant. Inclusion of the Rad55-Rad57 heterodimer with Rad51 and RPA results in a marked stimulation of strand exchange, providing evidence for a role of the Rad55-Rad57 heterodimer in overcoming the inhibitory effect of RPA.
\end{abstract}

[Key Words: S. cerevisiae; Rad55-Rad57 complex; RecA; recombination; RAD51]

Received February 18, 1997; revised version accepted March 26, 1997.

In Saccharomyces cerevisiae, genes of the RAD52 epistasis group function in the recombinational mode of DNA strand-break repair and are required for meiotic and mitotic genetic recombination. The RAD52 group includes the RAD50, RAD51, RAD52, RAD54, RAD55, RAD57, MRE11, and XRS2 genes. Among mutants of the $R A D 52$ group, those of the RAD52 gene generally exhibit the most severe defects in mitotic recombination (Ratray and Symington 1995; Sugawara et al. 1995). Interestingly, mutational inactivation of many of the aforementioned genes also results in meiotic inviability, which arises because of a requirement for meiotic recombination in ensuring the proper disjunction of chromosomal homologs in meiosis I (for review, see Petes et al. 1991). The structure and function of the RAD52 group genes have been conserved among eukaryotes.

In $S$. cerevisiae, the characterization of various chromosomal sites that exhibit a propensity to undergo meiotic recombination has revealed the formation of meiosis-specific DNA double-strand breaks at these sites. Subsequent to double-strand-break formation, $5^{\prime}$ to $3^{\prime}$ exonucleolytic processing of both ends of the DNA break generates $3^{\prime}$ overhanging single-strand DNA (ssDNA)

\footnotetext{
${ }^{1}$ Present address: Institute of Biotechnology and Center for Molecular Medicine, University of Texas Health Science Center at San Antonio, San Antonio, Texas 78245-3207 USA.

E-MAIL sung@uthscsa.edu; FAX (210) 5677277.
}

tails of $~ 600$ bases long (Cao et al. 1990; Sun et al. 1991). Genetic evidence strongly suggests that the ssDNA tails so formed represent the substrate that is utilized by recombination proteins for promoting the interaction with the homologous chromosomal partner. On the basis of the conceptual model of Szostak et al. (1983), it may be expected that nucleation of recombination proteins onto the $3^{\prime}$ ssDNA tails arising from double-strand-break processing leads to homology search, resulting in the pairing with the chromosomal homolog and the creation of heteroduplex DNA, the length of which is then extended by strand exchange. Concurrent and subsequent events include DNA synthesis, branch migration to further extend the heteroduplex region, and resolution of DNA intermediates, leading to the formation of mature recombinants. Because mitotic recombination and the repair of DNA double-strand breaks also share the requirement for the $R A D 52$ group genes, these processes very likely proceed via a similar or the same mechanistic route as meiotic recombination.

In the DNA double-strand break model for genetic recombination (Szostak et al. 1983), the formation of heteroduplex DNA between the $3^{\prime}$ overhanging ssDNA tails that result from break processing and the intact chromosomal homolog represents the key initial step. Results from a number of genetic analyses have strongly indicated a direct role of the RAD51, RAD52, RAD54, $R A D 55$, and RAD57 genes in the formation of heterodu- 
plex DNA between recombining chromosomes. Of these genes, RAD51, RAD55, and RAD57 are of particular interest because of the similarity of their encoded products to one another (Lovett 1994) and to the Escherichia coli RecA protein (Shinohara et al. 1993; Lovett 1994), which plays a central role in DNA repair and genetic recombination via its ability to catalyze pairing and strand exchange between homologous DNA molecules.

The homologous pairing and strand-exchange activity of RecA protein has been studied extensively with the model in vitro system that utilizes circular ssDNA and linear double-strand DNA (dsDNA). In the earliest or presynaptic phase of this reaction, RecA protein, in the presence of ATP, polymerizes on the ssDNA to form a nucleoprotein filament in which the DNA is held in an extended conformation. Heteroduplex formation, or strand exchange, between the ssDNA in the RecA filament and the incoming dsDNA commences from the 3' end of the strand in the dsDNA that is complementary to the ssDNA circle bound in the filament /Cox and Lehman 1987; Radding 1991; Kowalczykowski et al. 1994). In the presence of ATP, Rad51 protein also forms nucleoprotein filaments on DNA that are highly similar in structure to those formed by RecA (Ogawa et al. 1993; Sung and Robberson 1995), and Rad51 has been shown to catalyze homologous pairing and strand exchange (Sung 1994) within the context of the Rad51-ssDNA filament (Sung and Robberson 1995). Despite these resemblances to RecA, strand exchange by Rad51 initiates from the $5^{\prime}$ end of the complementary strand in the dsDNA, a reaction polarity opposite to that of RecA (Sung and Robberson 1995). The change of lysine-191, located in the Walker type A ATP-binding motif in Rad51 protein, to alanine results in a mutant rad51 protein that lacks pairing and strand-exchange activity (Sung and Stratton 1996 ) and that is biologically inactive (Shinohara et al. 1993; Sung and Stratton 1996), providing direct evidence that the Rad51 pairing and strand-exchange activity is required for genetic recombination.

The aforementioned studies on the RAD51-encoded product have yielded valuable information regarding its molecular function. However, the manner in which the two other RecA/Rad51 homologs-Rad55 and Rad57 proteins-influence the formation of heteroduplex DNA is not known. Here, biochemical studies are undertaken to delineate the molecular role of the Rad55 and Rad57 proteins in the recombination process. It is shown by several independent means that Rad55 and Rad57 proteins exist as a highly stable heterodimer in yeast cells. Evidence is presented that the Rad55-Rad57 heterodimer is indispensable for efficient pairing and strand exchange when RPA is added with Rad51 protein during the presynaptic phase. These results identify the function of the Rad55-Rad57 heterodimer in Rad51-mediated DNA pairing and strand exchange, and they help formulate a framework for understanding the biochemical interactions among the Rad51 recombinase, the heterotrimeric ssDNA-binding factor replication protein A (RPA), and the Rad55-Rad57 heterodimer in genetic recombination.

\section{Results \\ RAD55- and RAD57-encoded products exist as a complex}

Mutants of RAD55 and RAD57 genes, including null mutants, are cold sensitive for recombination (Lovett and Mortimer 1987; Hays et al. 1995; Johnson and Symington 1995), a unique property that is not seen with mutants of the other members of the RAD52 group. The rad55 and rad57 single mutants exhibit the same degree of recombination defect as the rad55-rad57 double mutant, indicating epistasis. Furthermore, with the aid of the yeast two-hybrid system, Rad55 and Rad57 proteins have been found to interact in vivo (Hays et al. 1995; Johnson and Symington 1995). Taken together, the results from previous genetic studies suggest that Rad55 and Rad57 proteins may mediate their biological roles together as a complex.

To address whether there is a stable complex of Rad55 and Rad57 proteins in yeast cells, portions of the Rad55 and Rad57 proteins were first expressed in E. coli, purified, and used as antigens for raising polyclonal antibodies in rabbits. Antibodies specific for Rad55 and Rad57 proteins were isolated from rabbit sera by affinity chromatography and then coupled to protein A-agarose beads for use in immunoprecipitation experiments. Rad55 protein immunoprecipitated from yeast extract consists of a main band of relative molecular mass of $46 \mathrm{kD}$ and minor species that migrate above the main band (Fig. 1A). These Rad55 protein species are overproduced $\sim 30$-fold in yeast cells harboring plasmid pR55.1, a multicopy plasmid that contains the RAD55 gene under the control of the yeast phosphoglycerate kinase $(P G K)$ promoter. Rad57 protein isolated from wild-type yeast extract by immunoprecipitation shows a main band at $52 \mathrm{kD}$ and minor species migrating above the main band (Fig. 1B). These Rad57 species are overproduced $\sim 30$-fold in yeast cells harboring plasmid pR57.1, a multicopy plasmid in which the RAD57 gene is under the control of the yeast alcohol dehydrogenase I $(A D C I)$ promoter. The major species of Rad55 and Rad57 observed in SDS-PAGE agree with the predicted sizes of $46 \mathrm{kD}$ for Rad55 protein and of $52 \mathrm{kD}$ for Rad57 protein (Kans and Mortimer 1991; Lovett 1994). The slower migrating species of Rad55 and Rad57 (Fig. 1A,B) could arise from post-translational modification of the proteins, but this remains to be determined experimentally.

Interestingly, by use of protein A-agarose bearing either anti-Rad55 or anti-Rad57 antibodies as immunobeads, coprecipitation of Rad55 and Rad57 proteins from wild-type yeast extract was seen (Fig. 2A). The amount of Rad55 or Rad57 that was coprecipitated by antibodies specific for the other protein was very similar to that precipitated directly by its cognate antibodies, which indicated that all or nearly all of the cellular Rad55 and Rad57 proteins are, in fact, physically associated. The amount of coprecipitating Rad55 and Rad57 proteins increased with simultaneous overexpression of the two proteins, as when extract from yeast cells harboring the overproducing plasmids pR55.1 (PGK- 
A

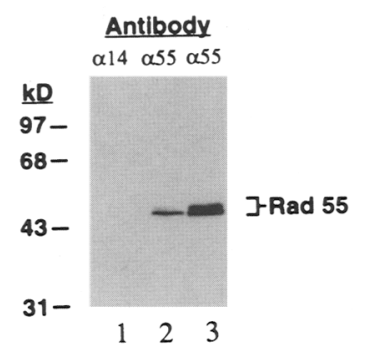

B

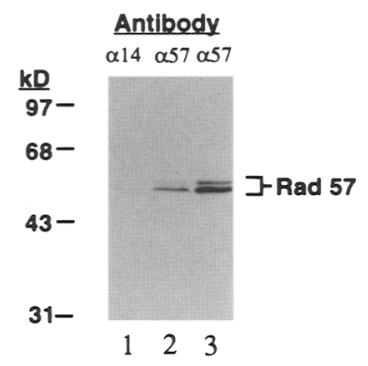

Figure 1. Identification of the Rad55 and Rad57 proteins in yeast cells. $|A|$ Immunoprecipitation of Rad55 protein. Extract from wild-type yeast strain LP2749-9B (lanes 1,2) and extract from LP2749-9B harboring the Rad55-overproducing plasmid pR55.1 (lane 3) were incubated with protein A-agarose beads bearing affinity-purified antibodies specific for Rad14 $\{\alpha 14$; lane 1) and for Rad55 $(\alpha 55$; lanes 2,3$\rangle$. After washing with buffer, the immunoprecipitates were treated with SDS to elute the bound proteins, and the SDS eluates were subjected to immunoblot analysis with anti-Rad55 antibodies. Lanes 1 and 2 contain the equivalent of $5 \times 10^{8}$ cells and lane 3 contains the equivalent of $5 \times 10^{7}$ cells. $(B)$ Immunoprecipitation of Rad57 protein. Extract from wild-type strain LP2749-9B (lanes 1,2) and extract from LP2749-9B harboring the Rad57 overproducing plasmid pR57.1 (lane 3) were incubated with protein A-agarose beads bearing anti-Rad14 ( $\alpha 14$; lane 1$)$ and anti-Rad57 ( $\alpha 57$; lanes 2,3 ) antibodies. The blot containing the SDS eluates of the immunoprecipitates was probed with anti-Rad57 antibodies. Lanes 1 and 2 contain the equivalent of $5 \times 10^{8}$ cells and lane 3 contains the equivalent of $5 \times 10^{7}$ cells.

RAD55) and pR57.1 (ADCI-RAD57) was used for immunoprecipitation (Fig. $2 B$ ), consistent with the premise and with results from additional experiments (see below) that complex formation between the two proteins occurs directly. Control experiments confirmed that the antiRad57 antibodies used do not precipitate Rad55 protein in the absence of Rad57 protein and, likewise, that antiRad55 antibodies have no affinity for Rad57 protein in the absence of Rad55 protein (data not shown). Thus, Rad55 and Rad57 proteins exist as a complex in yeast cells.

The molar cellular abundance of the Rad55-Rad57 heterodimer is $-10 \%$ that of the Rad51 protein, and no coprecipitation of the heterodimer with Rad51 has been observed under the same reaction conditions with protein A-agarose beads bearing anti-Rad51, anti-Rad55, or anti-Rad57 antibodies (data not shown). These observations indicate that the Rad55-Rad57 heterodimer is not stably associated with Rad51 protein in cell extract.

\section{Purification of the Rad55-Rad57 complex}

For purification of the Rad55-Rad57 complex, the protease-deficient yeast strain LP2749-9B coharboring the Rad55- and Rad57-overproducing plasmids pR55.1 and pR57.1 and the scheme summarized in Figure 3A were used. Rad55-Rad57 complex from the last step of purifi- cation in Mono Q (Fraction VI) was analyzed by SDSPAGE and found to be nearly homogeneous (Fig. 3B). The identity of the Rad55-Rad57 complex was established by immunoblotting (Fig. 3C). Densitometric scanning of the Coomassie blue stained gel containing Fraction VI protein revealed an essentially equimolar ratio of Rad55 protein species to Rad57 protein species (1-1.03) in the complex. From the 800 grams of starting yeast paste, 80 ug of the Rad55-Rad57 complex was obtained. During purification, the Rad55 and Rad57 proteins remained associated in column fractions that contained as little as $2 \times 10^{-10} \mathrm{M}$ of the complex, indicating a dissociation constant of the Rad55-Rad57 complex that is significantly lower than this protein concentration. The purified Rad55-Rad57 complex did not contain any Rad51 protein as revealed by immunoblot analysis of $1 \mu \mathrm{g}$ of the preparation with anti-Rad51 antibodies (Sung 1994) under conditions that could have detected $\leqslant 1$ ng of Rad51 protein (data not shown).

\section{Rad55-Rad57 complex is heterodimeric and highly stable}

The elution profile of the Rad55-Rad57 complex from

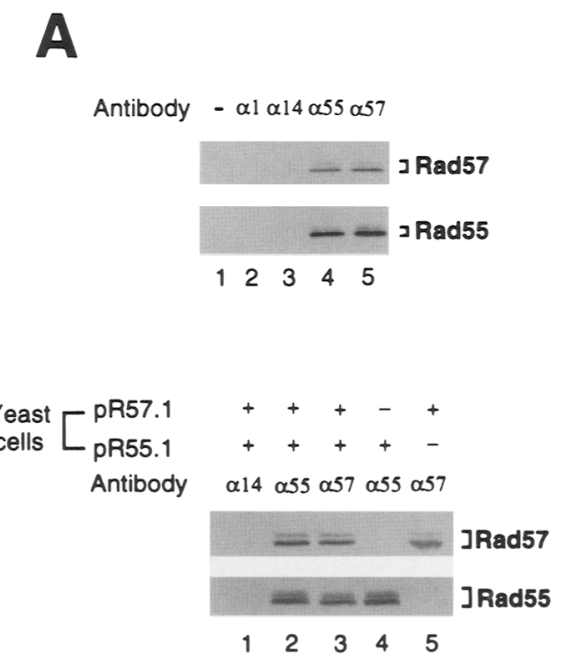

Figure 2. Coimmunoprecipitation of Rad55 and Rad57 proteins. (A) Extract from wild-type strain LP2749-9B was incubated with protein A-agarose beads with no antibody (lane 1) and with affinity-purified anti-Rad1 $(\alpha 1$; lane 2$)$, anti-Rad14 $(\alpha 14$; lane 3), anti-Rad55 ( $\alpha 55$; lane 4), and anti-Rad57 ( $\alpha 57$; lane 5) antibodies. The SDS eluates from these immunoprecipitations were probed for their contents of Rad55 and Rad57. The equivalent of $5 \times 10^{8}$ cells were loaded in all the lanes. $(B)$ Extracts from strain LP2749-9B harboring pR55.1, pR57.1, or both of these plasmids were incubated with protein A-agarose beads bearing anti-Rad14 ( $\alpha 14)$, anti-Rad55 ( $\alpha 55)$, and anti-Rad57 ( $\alpha 57)$ antibodies, and the SDS eluates from these immunoprecipitations were probed for their contents of Rad55 and Rad57 proteins. The equivalent of $5 \times 10^{7}$ cells were loaded in all the lanes. The wild-type level of Rad57 that coprecipitated with the overproduced Rad55 protein in lane 4, and the wild-type level of Rad55 that coprecipitated with the overproduced Rad57 protein in lane 5 , were too low to visualize under the conditions used. 
Figure 3. Purification of the Rad55-Rad57 complex. (A) Purification scheme. (B) Purity analysis. A $10 \%$ denaturing polyacrylamide gel containing $2 \mu \mathrm{g}$ of the purified Rad55-Rad57 complex (lane 2) and size standards (lane 1) was stained with Coomassie blue. (C) Immunoblot analysis. Nitrocelluose strips containing $40 \mathrm{ng}$ of the purified Rad55-Rad57 complex were probed with anti-Rad55 (lane 1) and anti-Rad57 antibodies (lane 2).
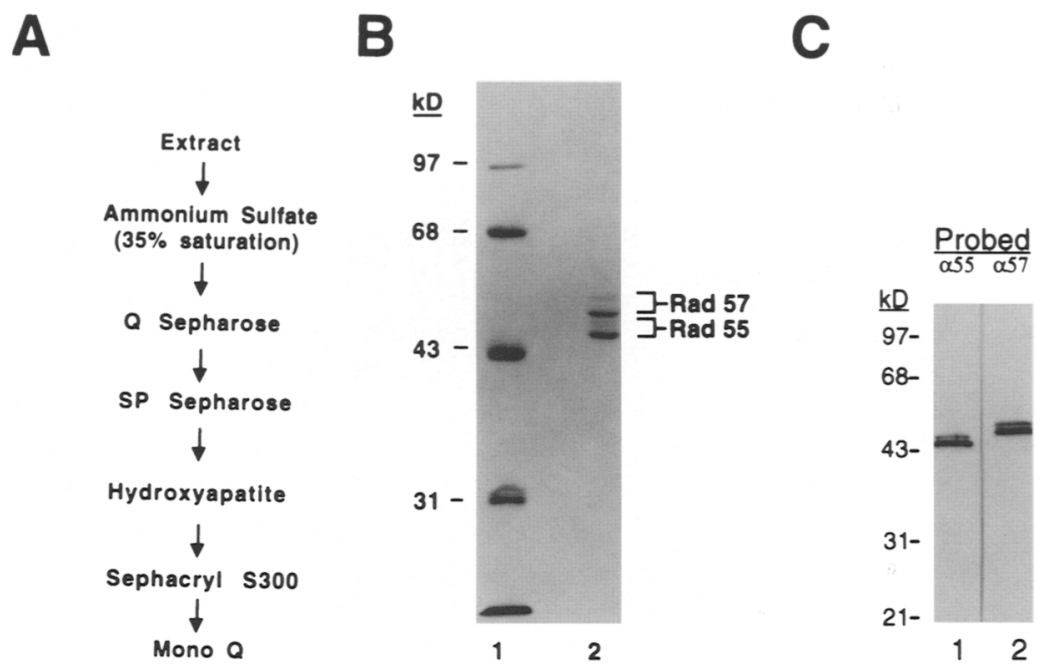

the Sephacryl S300 column, used as the penultimate purification step, is shown in Figure 4A. The bulk $(>95 \%)$ of the complex eluted from the molecular sizing column between fractions 39 and 45 , corresponding to $55 \%$ and $64 \%$ of the column volume, with a small portion $(<5 \%)$

\section{A}

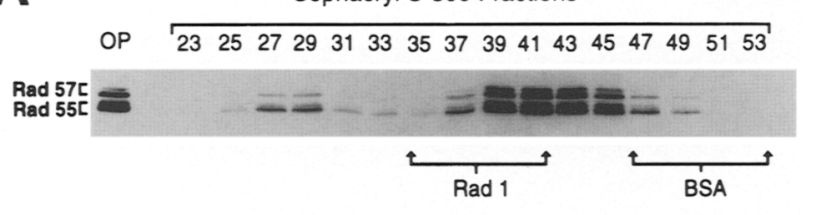

B

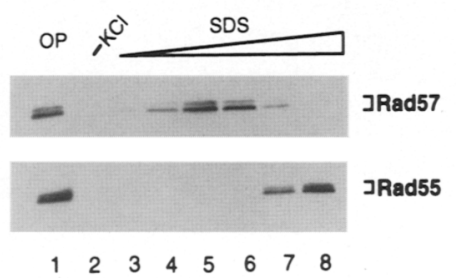

Figure 4. Rad55-Rad57 complex is heterodimeric and highly stable. (A) Molecular sizing analysis of the Rad55-Rad57 complex. Fractions 23 to 53 from the penultimate step of Rad55Rad57 complex purification in a Sephacryl S300 column and the column onput $(\mathrm{OP})$ were subjected to immunoblot analysis. Rad1 protein $(M 126 \mathrm{kD})$ eluted from the same column in fractions 35 to 41 as marked, and bovine serum albumin (BSA; $M 68$ $\mathrm{kD}$ ) eluted from the same column in fractions 47 to 53 as marked; the void volume of the column was from fractions 25 to 29 as determined by dextran blue exclusion (not marked). (B) Stability of the Rad55-Rad57 complex. Purified Rad55-Rad57 complex was immobolized on protein A-agarose beads bearing anti-Rad55 antibodies, and the immunocomplex was subjected to treatment with $1 \mathrm{M} \mathrm{KCl}$, followed by $0.05 \%, 0.1 \%, 0.2 \%$, $0.3 \%, 0.5 \%$, and $1 \%$ SDS. The onput material (OP; lane 1 ), the $1 \mathrm{M} \mathrm{KCl}$ wash (lane 2), and the various SDS eluates (lanes 3-8) were probed for their content of Rad55 and Rad57 proteins. of the complex eluting near or in the column void volume in fractions 25 to 29 . The elution position of the main peak of the Rad55-Rad57 complex was intermediate between those of bovine serum albumin $(M, 68 \mathrm{kD})$ and yeast Radl protein (M, $126 \mathrm{kD}$; Reynolds et al. 1987). Because the combined molecular mass of Rad55 protein $(46 \mathrm{kD})$ and Rad57 protein $(52 \mathrm{kD})$ is $98 \mathrm{kD}$, and because the two proteins are present in equimolar ratio in the complex, the results from this sizing analysis indicated that the bulk of the Rad55-Rad57 complex consisted of one molecule each of Rad55 and Rad57 proteins and was thus a heterodimer. The small fraction of Rad55-Rad57 complex that was found near or in the void volume also contained an equimolar ratio of Rad55 and Rad57 proteins, and, therefore, likely represented aggregates of the heterodimeric unit of the complex. The functional significance of the Rad55-Rad57 heteromultimers is unclear, as extremely low yields of these Rad55-Rad57 heteromultimeric species were obtained when attempts were made to concentrate or purify them further.

To define the avidity of the interaction between Rad55 and Rad57 proteins, the purified Rad55-Rad57 heterodimer was immobolized on anti-Rad55 immunobeads and washed sequentially at $25^{\circ} \mathrm{C}$ with $1 \mathrm{M} \mathrm{KCl}$ followed by increasing concentrations of SDS to determine what percentage of Rad57 was dissociated from Rad55 by these treatments. Figure $4 \mathrm{~B}$ shows that little, if any, of the Rad55-Rad57 complex was disrupted by $1 \mathrm{M} \mathrm{KCl}$, indicating that the complex is refractory to this salt. Densitometric scanning of the immunoblot in Figure $4 \mathrm{~B}$ revealed that $4 \%, 12 \%, 42 \%, 31 \%, 10 \%$, and $1 \%$ of $\operatorname{Rad} 57$ protein were eluted by $0.05 \%, 0.1 \%, 0.2 \%, 0.3 \%, 0.5 \%$, and $1 \%$ of SDS, indicating that the complex is, in fact, partially stable to this protein denaturant as well. Because Rad55 protein was bound by its cognate antibodies in the immunocomplex, $0.5 \%$ to $1 \%$ SDS was needed for its elution (Fig. 4B).

Taken together, the results indicated that Rad55 and Rad57 proteins exist as a highly stable heterodimer in yeast cells, with an apparent dissociation constant of 
$<2 \times 10^{-10} \mathrm{M}$. Biochemical experiments detailed below revealed the molecular function of the Rad55-Rad57 heterodimer in the strand-exchange reaction.

\section{Effects of RPA on pairing and strand exchange mediated by Rad51}

With Rad51 protein and RPA, the standard strand-exchange reaction is assembled by first incubating ssDNA with Rad51 protein at ratios of 2.5 to 3 nucleotides per Rad51 monomer for $5 \mathrm{~min}$, followed by the addition of RPA at 24 nucleotides per RPA molecule and another 5 -min incubation, before the linear dsDNA is incorporated to complete the reaction mixture. The reaction products-the joint molecules and circular duplex (Fig.
$5 \mathrm{~A}$-are resolved from the input DNA substrates in an agarose gel and visualized by staining with ethidium bromide. The results of such a reaction are shown in Figure 5B. After 48 and $84 \mathrm{~min}$ of reaction time, the levels of products were, respectively, 75\% $168 \%$ nicked circular duplex and $7 \%$ joint molecules) and $85 \%$ (80\% nicked circular duplex and $5 \%$ joint molecules) of the input linear duplex (Figs. 5B,D). As reported in previous studies (Sung 1994; Sung and Robberson 1995; Sung and Stratton 1996), the omission of RPA from an otherwise identical reaction resulted in a marked reduction of products, such that only $4.5 \%$ of the input linear duplex had been converted into joint molecules and $\leqslant 1 \%$ into nicked circular duplex after $84 \mathrm{~min}$ of reaction time (Fig. 5B,D).

During the presynaptic phase in the standard reaction, RPA is incorporated after Rad51 (Fig. 5B). It was reasoned

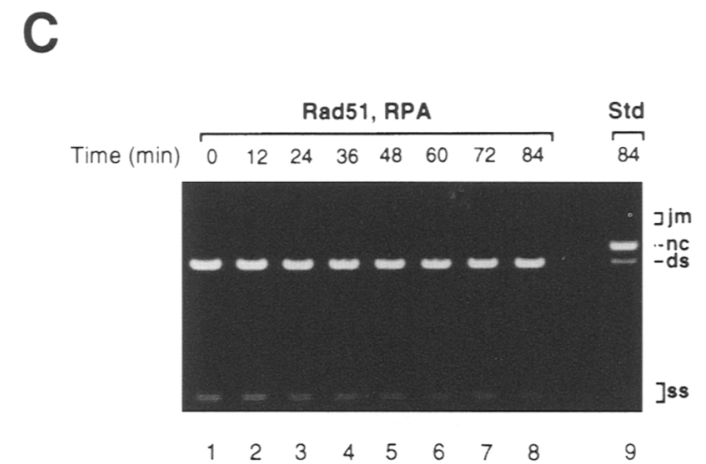

A

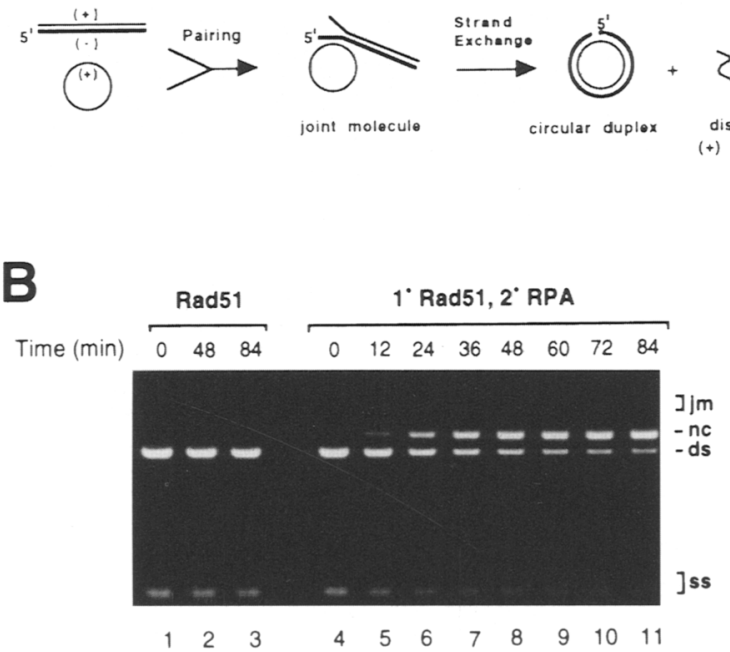

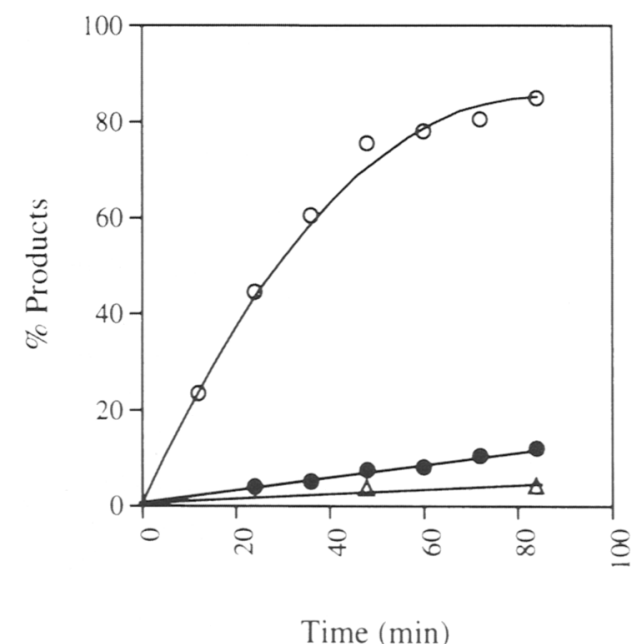

Figure 5. Effects of RPA on Rad51-mediated pairing and strand exchange. $(A)$ The DNA substrates [viral $(+)$ strand and linear duplex from $\phi \mathrm{X} 174$ ] and reaction products [joint molecules, nicked circular duplex, and displaced $(+)$ strand] of the pairing and strand-exchange reaction. $(B)$ RPA is required for efficient pairing and strand-exchange. Time course of pairing and strand-exchange reactions wherein either only Rad51 was used (lanes 1-3) or RPA was added after preincubation of Rad51 with the ssDNA substrate (lanes 4-11). (C) Coaddition of RPA with Rad51 reduces efficiency of pairing and strand exchange. Time course (lanes 1-8) of a pairing and strandexchange reaction wherein ssDNA was incubated with Rad51 and RPA simultaneously. The 84-min time point (lane 9) of a standard reaction (Std) wherein RPA was added after the ssDNA had been preincubated with Rad51 is included for comparison. (jm) Joint molecules; (nc) nicked circular duplex; (ds) input linear duplex; (ss) the faster migrating form is the input viral $(+\mid$ strand and the slower migrating form is the displaced linear $(+)$ strand. $(D)$ Graphical representation of the results in $B$ and $C$. (\% Products) Sum of joint molecules and nicked circular duplex formed at each time point. $(O)$ Results from lanes 4 to 11 of $(B) ;(\triangle)$ results from lanes $1-3$ of $B$; and $(1)$ results from lanes $1-8$ of $C$. 
that during recombination in vivo, RPA most likely is present during the nucleation of Rad51 protein onto the ssDNA region that results from double-strand-break processing. Therefore, it was of considerable interest to determine the effect of including RPA at the time Rad51 protein nucleates onto the ssDNA. Unexpectedly, when RPA was added together with Rad51 protein, the level of pairing and strand exchange decreased to a level that was insignificant compared to that seen in the standard reaction. As shown in Figure 5,C and D, in the case where RPA and Rad51 protein were mixed together with ssDNA, the amounts of total products were $7 \% 13 \%$ nicked circular duplex and $4 \%$ joint molecules) and $-11 \%\{6 \%$ nicked circular duplex and $5 \%$ joint molecules) of the input linear duplex after 48 and $84 \mathrm{~min}$ of reaction, respectively, which were surprisingly low, considering that in the standard reaction $\sim 75 \%$ of the input linear duplex had been converted into products after only 48 min (Fig. 5B,D).

\section{The Rad55-Rad57 heterodimer promotes pairing and strand exchange by Rad51}

The results from the experiments above indicated that the inclusion of RPA during the presynaptic phase to mimic what is expected to occur in vivo results in a low level of pairing and strand exchange. One simple and probable explanation for this observation is that whereas RPA facilitates Rad51 filament assembly by melting away secondary structure in the ssDNA (Sung 1994; Sung and Robberson 1995), it also competes with Rad51 for binding to ssDNA, thus reducing the quantity of Rad51 that can be loaded onto the ssDNA and consequently interfering with the assembly of Rad51-ssDNA nucleoprotein filaments. This supposition is congruent with the observation that $E$. coli single-strand binding protein (SSB), although an important cofactor in the RecA-mediated strand-exchange reaction, can also exclude RecA from ssDNA if added to the ssDNA prior to the introduction of RecA, thus causing a delay in the formation of pairing and strand-exchange products (Umezu et al. 1993).

Given the paradoxical effects of RPA on Rad51-mediated pairing and strand exchange and the fact that heteroduplex formation during recombination also requires the action of other proteins in the RAD52 group, the possibility that Rad55 and Rad57 may overcome the inhibitory effect of RPA was considered. To examine this hypothesis directly, increasing amounts of the purified Rad55-Rad57 heterodimer $(0.25,0.37$, and $0.74 \mu \mathrm{M})$ and quantities of Rad51 protein $(6.8 \mu \mathrm{M})$, RPA $(0.76 \mu \mathrm{M})$, and ssDNA $(18.4 \mu \mathrm{M})$ the same as those used in the experiment described earlier (Fig. 5) were incubated simultaneously for $10 \mathrm{~min}$ to allow for loading of protein factors onto ssDNA, and, following the incorporation of the linear dsDNA, a portion of the reaction was withdrawn at different time points and processed for agarose gel electrophoresis to quantify the amount of pairing and strandexchange products. Interestingly, a Rad55-Rad57 heterodimer concentration-dependent stimulation of pairing and strand exchange was observed. A time course experiment wherein the Rad55-Rad57 heterodimer was added to $0.74 \mu \mathrm{M}$ is shown in Figure 6. Compared with an otherwise identical reaction that lacked the Rad55-Rad57 complex (Fig. 5C), the level of pairing and strand exchange obtained with Rad55-Rad57 heterodimer present in the reaction was much higher throughout the entire time course (Fig. 6A,B), to a level comparable to that achieved in the standard reaction. Specifically, in the reaction that contained the Rad55-Rad57 heterodimer, after 48 and 84 min of reaction, $43 \%$ (36\% nicked circular duplex) and $60 \%$ (53\% nicked circular duplex) of the input linear duplex had been converted into products (Fig. 6B), respectively, as compared with $7 \%$ (3\% nicked circular duplex) and $11 \%$ (6\% nicked circular duplex) of products seen in the absence of the heterodimer after the same reaction times (Figs. 5D and $6 \mathrm{~B}$ ).

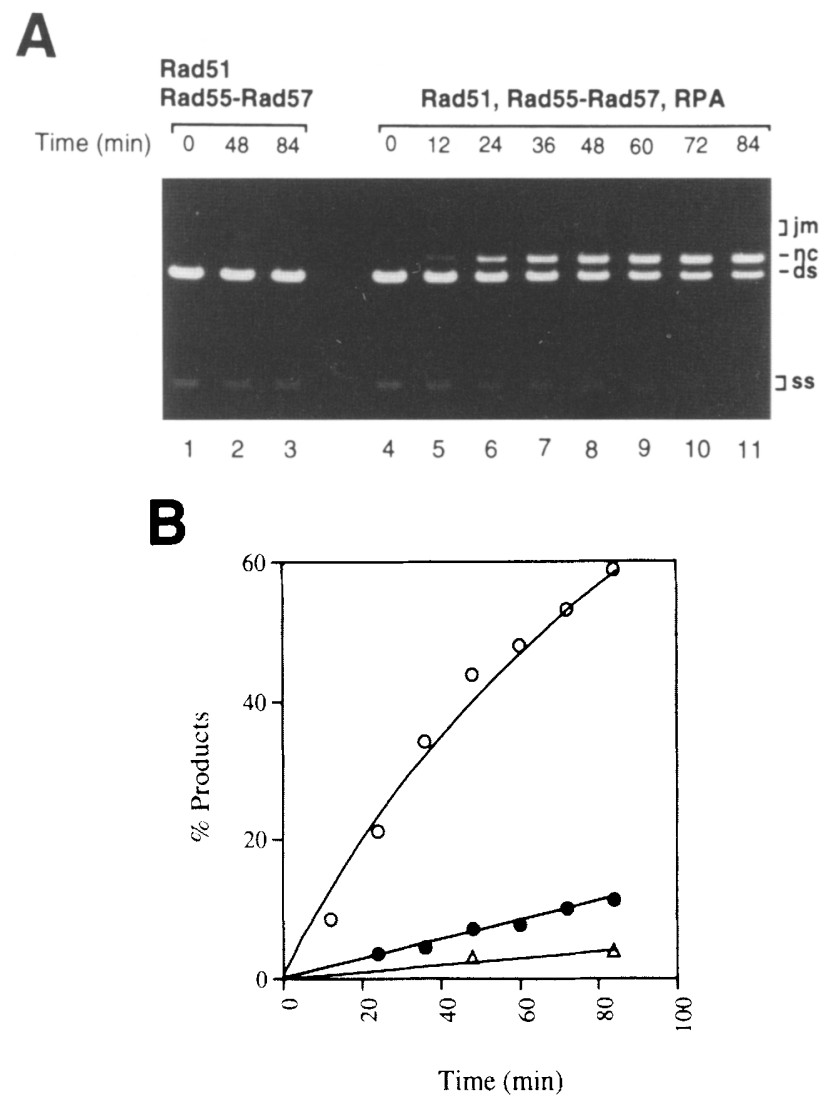

Figure 6. Rad55--Rad57 heterodimer functions with RPA to promote pairing and strand exchange by Rad51. Time course of pairing and strand-exchange reactions in which the ssDNA was incubated during the presynaptic stage with $\operatorname{Rad} 51$ and the Rad55-Rad57 heterodimer simultaneously (lanes 1-3) or with Rad51, Rad55-Rad57 heterodimer, and RPA simultaneously (lanes 4-11). Symbols are as described in Fig. 5 legend. $(B)$ Graphical representation of the results in $A$ and of those shown in Fig. 5C. (\% Products) Sum of the joint molecules and nicked circular duplex formed at each time point. (O) Results from lanes 4-11 of $A ;(\triangle)$ results from lanes $1-3$ of $A ;(\bullet)$ results from lanes $1-8$ of Fig. $5 \mathrm{C}$. 
Because the Rad55-Rad57 heterodimer exerts a remarkable stimulatory effect on the pairing and strandexchange reaction, and because both subunits of this heterodimer exhibit homology to the Rad51 protein (Lovett 1994), the possibility that Rad55-Rad57 complex might catalyze homologous pairing and strand exchange independent of the Rad51 protein was considered. In the absence of Rad51 protein, however, over the range of Rad55-Rad57 heterodimer concentrations used in the experiments with Rad51 and RPA and at an increased concentration of the heterodimer $(1.48 \mu \mathrm{M})$, no pairing and strand-exchange activity in the Rad55-Rad57 complex was detected under the conditions described in this work or at higher and lower $\mathrm{pH}$ values $(\mathrm{pH} 8.0,7.5$, and 6.5 ), regardless of whether or not RPA was added to the reaction during or after incubation of the $\operatorname{Rad} 55-\operatorname{Rad} 57$ complex with the ssDNA (data not shown). The possibility that the Rad55-Rad57 complex might functionally replace RPA and exclude the latter from binding to ssDNA was also examined. As shown in Figure 6A, lanes $1-3$, in the absence of RPA, the amount of pairing and strand exchange obtained with Rad51 plus the Rad55Rad57 heterodimer was essentially the same as the extremely low level seen with Rad51 alone (Fig. 5B,D), indicating that RPA is still required for efficient pairing and strand exchange. Preincubation of ssDNA with both Rad51 protein and the Rad55-Rad57 complex prior to the addition of RPA did not result in a higher level of strand exchange than what was obtained in the standard reaction in which the ssDNA was preincubated with Rad51 protein alone.

\section{Discussion}

\section{Rad55 and Rad57 proteins exist as a stable} heterodimer

By immunoprecipitation, it was found that in wild-type yeast cells, the majority or all of the Rad55 and Rad57 proteins are physically associated in a complex. The Rad55-Rad57 complex has been purified to near homogeneity from yeast cells cooverproducing the two proteins. Purified Rad55-Rad57 complex contains an equimolar amount of the two proteins, and molecular sizing analysis has indicated that this complex is heterodimeric. During purification, the Rad55 and Rad57 proteins remained stably and quantitatively associated at concentrations as low as $2 \times 10^{-10} \mathrm{M}$. In addition, the Rad55-Rad57 complex is completely stable to $1 \mathrm{M} \mathrm{KCl}$ and even partially stable to low amounts of the protein denaturant SDS.

The finding that $\operatorname{Rad} 55$ and $\operatorname{Rad} 57$ proteins exist in a complex is congruent with observations from previous in vivo studies utilizing the yeast two-hybrid system (Hays et al. 1995; Johnson and Symington 1995), which yielded evidence that Rad55 and Rad57 interact physically. The results from these in vivo studies, however, could not distinguish whether the Rad55 and Rad57 proteins interact directly or do so through an intermediary, nor could they address the stoichiometry and avidity of this interaction. Results from immunoprecipitation and other experiments presented here now extend these in vivo results to indicate further that $\operatorname{Rad} 55$ and Rad57 interact directly, and that the protein complex is heterodimeric and highly stable.

\section{Effects of RPA and Rad55-Rad57 heterodimer on Rad51-mediated strand exchange}

For the discussion below, the levels of pairing and strand-exchange products achieved at the mid-point 148 $\mathrm{min}$ ) and the end point ( $84 \mathrm{~min}$ ) of the various experiments that employed different combinations and orders of addition of Rad51, Rad55-Rad57 heterodimer, and RPA are summarized in Figure 7. As reported in previous studies (Sung 1994; Sung and Robberson 1995; Sung and Stratton 1996) and shown in this work, in the absence of RPA, Rad51 protein carries out only a very limited amount of pairing and strand exchange, thus indicating an indispensable role of RPA in these reactions. When RPA is used in the standard strand-exchange protocol, it is incorporated after preincubation of $\operatorname{Rad} 51$ with the ssDNA substrate. Because RPA must also be present at the time Rad51 nucleates onto the ssDNA derived from double-strand-break processing during genetic recombination in vivo, it was of considerable interest to investigate the effect of including RPA at the time Rad51 is incubated with the ssDNA. Unexpectedly, when the order of addition of components was altered from what is done in the standard reaction to incubating the ssDNA

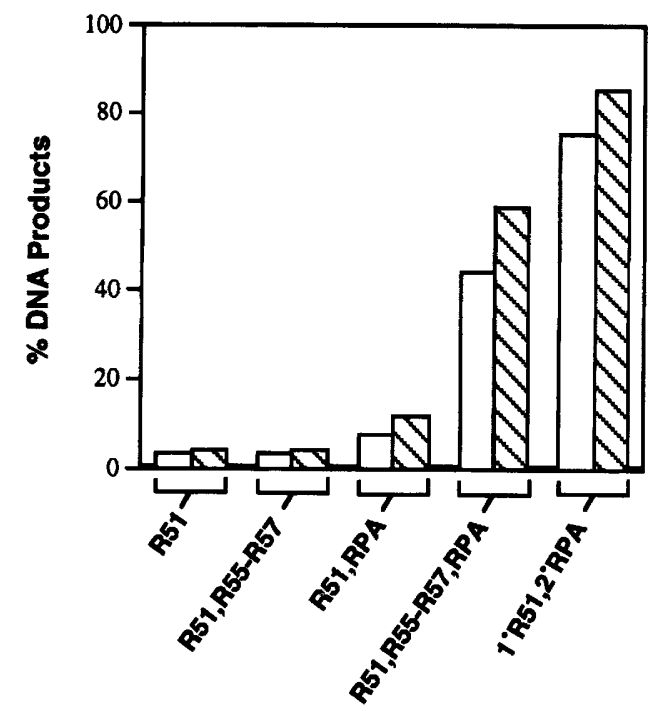

Figure 7. Summary of pairing and strand exchange with different combinations of protein factors. The sum of reaction products (joint molecules and nicked circular duplex) at the 48-min time point (open bars) and the 84 -min time point (hatched bars) for each combination of protein factors is shown. (R51) Rad51; (R55-R57) Rad55-Rad57 heterodimer. The protein factors were incubated together with ssDNA except in the last case $\left(1^{\circ} \mathrm{R} 51\right.$, $2^{\circ} \mathrm{RPA}$ ), wherein the ssDNA was preincubated with Rad51 protein before the incorporation of RPA. 
with RPA and Rad51 together, the efficiency of the reaction dropped rather drastically. Because the formation of DNA heteroduplex during genetic recombination also requires the participation of other proteins in the RAD52 group, it seemed probable that some of the other RAD52 group proteins including Rad55 and Rad57 may, in fact, function to enhance pairing and strand exchange by Rad51 and RPA. Consistent with this hypothesis, the inclusion of the purified Rad55-Rad57 heterodimer during the presynaptic phase results in a dramatic stimulation of the efficiency of pairing and strand exchange, to a level comparable to that seen in the standard reaction. Control experiments showed that Rad55-Rad57 heterodimer does not merely replace RPA in the process, because the latter is still required for efficient pairing and strand exchange. Thus, in addition to RPA (Sung 1994), the results here identify the Rad55-Rad57 heterodimer as another essential cofactor for the Rad51 recombinase.

In the absence of Rad51 protein, Rad55-Rad57 heterodimer, over the range of concentrations used in this work, exhibits no strand-exchange activity, regardless of whether RPA is absent, is added simultaneously with the Rad55-Rad57 heterodimer, or is added after a preincubation of ssDNA with the Rad55-Rad57 complex.

\section{Action mechanism of the Rad55-Rad57 heterodimer}

The degree of radiation sensitivity and other recombination defects in rad55 and rad57 mutants is more pronounced at low temperatures (Lovett and Mortimer 1987; Hays et al. 1995; Johnson and Symington 1995). Overexpression of the Rad51 protein in rad55 and rad57 mutants partially suppresses the radiation sensitivity and the defect in mitotic recombination of these mutants. Overproduction of Rad55 and Rad57, either singly or simultaneously, however, does not alleviate the recombination defects of a rad51 mutant. Likewise, overexpression of Rad55 and Rad57 proteins has no effect on the recombination defects of rad57 mutants and rad55 mutants, respectively (Hays et al. 1995; Johnson and Symington 1995). Taken together, these genetic studies suggested that during recombination, Rad55 and Rad57 proteins may serve to enhance the activity of Rad51 protein, possibly helping to overcome a rate limiting step in the pairing and strand-exchange reaction catalyzed by Rad51, and they further suggested that Rad55 and Rad57 proteins are both required in this capacity and that they fulfill distinct, nonoverlapping roles. Results from the biochemical studies documented here reveal a specific role of the Rad55-Rad57 heterodimer as a cofactor for the Rad51 recombinase, acting to overcome the challenge presented by RPA-binding to ssDNA. The function of the Rad55-Rad57 heterodimer in the Rad51 catalyzed strand-exchange reaction is reminiscent of that of the $E$. coli recombination proteins $\mathrm{RecF}$, RecO, and RecR, which act in concert to facilitate the utilization of ssDNA already coated with SSB for pairing and strand exchange by RecA (Umezu et al. 1993).

A plausible model for rationalizing the biological function of the Rad55-Rad57 complex might entail an avid- ity of the complex for ssDNA and, via protein-protein interactions, the DNA bound Rad55-Rad57 complex may facilitate the nucleation of Rad51 protein onto the DNA substrate, thereby maintaining an optimal ratio of RPA and Rad51 protein in the presynaptic nucleoprotein filament. Consistent with these ideas, in DNA mobility shift assays with $\phi X 174$ circular ssDNA and linear dsDNA as substrates in the presence of $80 \mathrm{~mm} \mathrm{KCl,}$ Rad55-Rad57 heterodimer binds readily to ssDNA, and to a much lesser degree, to dsDNA as well (data not shown). As for interaction with Rad51, Rad55 has been found to interact with Rad51 protein in the two-hybrid assay (Hay et al. 1995; Johnson and Symington 1995), although a complex of Rad51 with the Rad55-Rad57 heterodimer has not been observed in immunoprecipation experiments carried out under the conditions used $(300$ $\mathrm{mm} \mathrm{KCl}$ ) for coprecipitating the Rad55 and Rad57 proteins, indicating that Rad51 is not stably associated with the Rad55-Rad57 heterodimer in cell extract (data not shown). However, interaction of the purified Rad55Rad57 complex with Rad51 protein cross-linked to AffiGel 15 beads has been observed under milder conditions (70 mM KCl; data not shown). Taken together, it can be concluded that the Rad55-Rad57 complex indeed interacts directly with Rad51 protein, but this interaction is much less stable than that of Rad55 protein with $\operatorname{Rad} 57$ protein.

Rad55 and Rad57 proteins exhibit homology to Rad51 and RecA proteins (Lovett 1994), and they both contain Walker ATP-binding motifs, suggesting that they bind and hydrolyze ATP (Kans and Mortimer 1991; Lovett 1994). Consistent with this observation, we have found that purified Rad55-Rad57 heterodimer possesses an ATPase activity. Unlike the Rad51 ATPase activity, however, which is stimulated strongly by a DNA cofactor (Sung 1994), addition of ssDNA or dsDNA does not significantly affect ATP hydrolysis by the Rad55-Rad57 heterodimer (data not shown). In the genetic studies of Johnson and Symington (1995), mutation of the invariant lysine residue located in the Walker type A ATP-binding motif in Rad55 protein to either alanine or lysine resulted in partial inactivation of the RAD55 function, whereas the analogous mutations in the Rad57 protein had no measurable effect on recombination processes. Although the question regarding whether both subunits in the Rad55-Rad57 heterodimer are capable of binding and hydrolyzing ATP remains to be addressed, results from these genetic studies would suggest that only the function of Rad55 protein is stimulated by ATP-binding and hydrolysis (Johnson and Symington 1995).

In conclusion, the results presented here demonstrate a functional interaction among the Rad51 recombinase, the Rad55-Rad57 heterodimer, and RPA in the DNA strand-exchange reaction. Furthermore, it appears that the three RecA homologs-Rad51, Rad55, and Rad57rather than simply providing redundant and overlapping functions in genetic recombination, in fact, possess rather distinct biochemical properties and fulfill highly specific roles. Because of the remarkable degree of evolutionary conservation of the RAD52 group proteins, the 
yeast system should continue to serve as a highly useful paradigm for dissection of the molecular mechanisms of recombination in eukaryotes.

\section{Materials and methods}

\section{E. coli plasmids}

A portion of the RAD55 gene encompassing the carboxy-terminal 205 amino acid residues of the Rad55 protein was fused to the 15 amino-terminal residues of the $E$. coli transcriptional terminator rho $(\rho)$, yielding plasmid $\mathrm{pR} 55.2$. A portion of the RAD57 gene encompassing the amino-terminal 213 residues of the Rad57 protein was fused to the amino-terminal 116 residues of the $\rho$ protein, yielding plasmid pR57.2. In these plasmids, the expression of the $\rho$-Rad55 and $\rho$-Rad57 hybrid polypeptides is driven by the $\lambda \mathrm{P}_{\mathrm{L}}$ promoter.

\section{Polyclonal antibodies}

Plasmids pR55.2 and pR57.2 were introduced into E. coli strain AR120.A6, and the fusion proteins were induced by nalidixic acid treatment. The insoluble $\rho$-Rad55 and $\rho$-Rad57 fusion proteins were purified by preparative SDS-PAGE, dialyzed into phosphate-buffered saline $\left(10 \mathrm{mM} \mathrm{NaH}_{2} \mathrm{PO}_{4}\right.$ at $\mathrm{pH} 7.2,150 \mathrm{~mm}$ $\mathrm{NaCl}$, and used as antigens for production of antisera in rabbits, as described (Sung et al. 1987). The purified antigens were also covalently coupled to cyanogen bromide activated Sepharose $4 \mathrm{~B}$ (Pharmacia) for use as affinity matrix to purify antibodies from rabbit sera.

\section{Yeast plasmids}

For expression of Rad55 protein in yeast, the RAD55 gene from 72 nucleotides upstream of the translation initiation ATG codon until 549 nucleotides downstream of the translation stop TAA codon was placed under the control of the $P G K$ promoter in the multicopy plasmid pMA91 $(2 \mu, P G K, L E U 2-d$; Kingsman et al. 1990), yielding plasmid pR55.1. For expression of Rad57 protein, RAD57 gene from 30 nucleotides upstream of the translation initiation ATG codon until 162 nucleotides downstream of the translation stop TGA codon was placed under the control of the ADCI promoter in plasmid pSCW231 $(2 \mu, A D C I$, TRP1; Sung et al. 1987), yielding plasmid pR57.1.

\section{Purification of Rad55-Rad57 complex}

Yeast strain LP2749-9B (mata, his34-1, leu2-3, leu2-112, pep43 , trp1, ura3-52) harboring both pR55.1 and pR57.1 was precultured in complete synthetic medium lacking tryptophan and leucine, diluted with 10 volumes of fresh medium, and grown $12-14 \mathrm{hr}$ at $30^{\circ} \mathrm{C}$ to a density of $\sim 6 \times 10^{7} \mathrm{cells} / \mathrm{ml}$. Cells were harvested by centrifugation and stored frozen at $-70^{\circ} \mathrm{C}$. To prepare extract, 800 grams of frozen cell paste, obtained from 160 liters of culture, was thawed in cell breakage buffer in the presence of protease inhibitors and passed through a French press, as described (Sung et al. 1987). The cell lysate was clarified by centrifugation $(100,000 \mathrm{~g}$ for $90 \mathrm{~min})$, and then treated with ammonium sulfate at $0.21 \mathrm{~g} / \mathrm{ml}$ to precipitate the Rad55-Rad57 complex together with $\sim 15 \%$ of total protein. The ammonium sulfate precipitate was harvested by centrifugation $(20,000 \mathrm{~g}, 30$ $\mathrm{min})$, dissolved in $500 \mathrm{ml}$ of buffer $\mathrm{K}\left(20 \mathrm{mM} \mathrm{KH}_{2} \mathrm{PO}_{4}\right.$ at $\mathrm{pH} 7.4$, $10 \%$ glycerol, $0.5 \mathrm{~mm}$ EDTA, and $1 \mathrm{~mm}$ DTT) with protease inhibitors (Sung et al. 1987) to give conductivity equivalent to $80 \mathrm{~mm} \mathrm{KCl}$ (Fraction I, containing $4 \mathrm{mg}$ of Rad55-Rad57 complex $)$, and then applied onto a column of Q Sepharose $(2.5 \times 10.2$ $\mathrm{cm}$; total $50 \mathrm{ml}$ of matrix), which was developed with a $500-\mathrm{ml}$ gradient of $80-400 \mathrm{~mm} \mathrm{KCl}$ in buffer $\mathrm{K}$, collecting 50 fractions. The peak of Rad55-Rad57 complex, eluting at $\sim 240 \mathrm{~mm} \mathrm{KCl}$, was identified by immunoblotting, pooled (Fraction II, $80 \mathrm{ml}$, containing $1.5 \mathrm{mg}$ of the Rad55-Rad57 complex), and dialyzed against 2 liters of buffer $\mathrm{K}$ for $2 \mathrm{hr}$. The dialysate was clarified by centrifugation $(20,000 \mathrm{~g}, 20 \mathrm{~min})$ and loaded onto SP Sepharose $(1.5 \times 5.7 \mathrm{~cm}$; total $10 \mathrm{ml})$, which was developed with a $200-\mathrm{ml}$ gradient of 30 to $400 \mathrm{~mm} \mathrm{KCl}$ in buffer $\mathrm{K}$, collecting 50 fractions. The Rad55-Rad57 complex elutes from SP Sepharose at $\sim 180$ $\mathrm{mM} \mathrm{KCl}$, and the pool of which (Fraction III, $20 \mathrm{ml}$, containing $600 \mu \mathrm{g}$ of Rad55-Rad57 complex) was applied directly onto a column of Macro-Prep hydroxyapatite $(1.2 \mathrm{ml}$ matrix from BioRad packed in an HR5/5 column purchased from Pharmacia), which was developed with a $30-\mathrm{ml}$ gradient of $0-250 \mathrm{~mm}$ $\mathrm{KH}_{2} \mathrm{PO}_{4}$ in buffer $\mathrm{K}$ with $50 \mathrm{~mm} \mathrm{KCl}$, and collecting 30 fractions. The pool of Rad55-Rad57 complex (Fraction IV, $5 \mathrm{ml}$, containing $300 \mu \mathrm{g}$ of Rad55-Rad57 complex), which elutes at $\sim 120 \mathrm{mM} \mathrm{KH}_{2} \mathrm{PO}_{4}$ from hydroxyapatite, was concentrated to 0.6 $\mathrm{ml}$ with a Centricon-30 microconcentrator (Amicon), and then subjected to molecular sizing in a column of Sephacryl S300 HR $(1 \times 45 \mathrm{~cm}$; total $35 \mathrm{ml})$ in buffer $\mathrm{K}$ with $100 \mathrm{~mm} \mathrm{KCl}$. The $\mathrm{S} 300$ pool of Rad55-Rad57 complex (Fraction V, 4 ml, containing 140 $\mu \mathrm{g}$ of Rad55-Rad57 complex) was fractionated in Mono Q (HR5) 5; Pharmacia) using a $20 \mathrm{ml}$ gradient of 90 to $400 \mathrm{mM} \mathrm{KCl}$ in buffer $\mathrm{K}$, collecting 40 fractions. The pool of Rad55-Rad57 complex (Fraction VI, $80 \mu \mathrm{g}$ in $1.5 \mathrm{ml}$ ), eluting at $~ 250 \mathrm{~mm} \mathrm{KCl}$, was concentrated to $1.5 \mathrm{mg} / \mathrm{ml}$ and stored in small portions at $-70^{\circ} \mathrm{C}$. Fraction VI Rad55-Rad57 complex was nearly homogeneous, as determined by Coomassie blue staining of a $10 \%$ denaturing polyacrylamide gel containing $2 \mu \mathrm{g}$ of the purified complex (Fig. 3B). The overall recovery of the Rad55-Rad57 complex was about $2 \%$.

\section{Purification of Rad51 protein}

Rad51 protein was purified to near homogeneity from yeast strain LP2749-9B harboring plasmid pR51.3, containing the $R A D 51$ gene under the control of the yeast phosphoglycerate kinase promoter, as described previously (Sung 1994). The Rad51 protein was stored in $10 \mathrm{mM} \mathrm{KH}_{2} \mathrm{PO}_{4}$ at $\mathrm{pH} 7.4$, containing $350 \mathrm{~mm} \mathrm{KCl}, 1 \mathrm{~mm} \mathrm{DTT}$, and $0.5 \mathrm{~mm}$ EDTA.

\section{Purification of RPA}

Yeast RPA was purified to near homogeneity with a protocol modified from those described by Brill and Stillman (1989) and by Henricksen et al. (1994). Briefly, extract was prepared from 1 $\mathrm{kg}$ of yeast strain LP2749-9B in buffer A $(25 \mathrm{~mm}$ Tris- $\mathrm{HCl}$ at $\mathrm{pH}$ 7.5, 10\% glycerol, $1 \mathrm{~mm}$ EDTA, $1 \mathrm{~mm}$ DTT) containing $100 \mathrm{~mm}$ $\mathrm{KCl}$ and protease inhibitors (Sung et al. 1987). After centrifugation $(100,000 \mathrm{~g}$ for $90 \mathrm{~min})$, the clarified extract (Fraction I; 1.3 liters) was applied onto a column of Affi-Gel Blue (5 $\times 6 \mathrm{~cm} ; 118$ $\mathrm{ml}$ matrix) that was washed with $500 \mathrm{ml}$ of buffer A containing $800 \mathrm{mM} \mathrm{KCl}$, and then eluted with a $500-\mathrm{ml}$ gradient of 0.5 to $2.5 \mathrm{M} \mathrm{NaSCN}$ in buffer A. Fractions containing RPA, which eluted at $\sim 1.5 \mathrm{M} \mathrm{NaSCN}$, were pooled to give Fraction II ( $80 \mathrm{ml}$ ), which was dialyzed against buffer A containing $0.5 \mathrm{M} \mathrm{NaCl}$ and protease inhibitors, and fractionated in a column of ssDNA cellulose $(2.5 \times 5 \mathrm{~cm} ; 24.5 \mathrm{ml}$ of matrix from USB) with a $120-\mathrm{ml}$ gradient from 0.75 to $2.5 \mathrm{M} \mathrm{NaCl}$ and $40 \%$ ethylene glycerol in buffer A. RPA eluted at about the middle of the gradient. The RPA pool (Fraction III; $20 \mathrm{ml}$ ) was dialyzed for $12 \mathrm{hr}$ against 2 liters of buffer A containing $100 \mathrm{mM} \mathrm{KCl}, 20 \%$ sucrose, and protease inhibitors, and fractionated in a column of Bio-Gel HTP hydroxyapatite $(1 \times 5 \mathrm{~cm} ; 3.9 \mathrm{ml}$ of matrix) with a $50-\mathrm{ml}$ 
gradient from 0 to $125 \mathrm{mM} \mathrm{KH}_{2} \mathrm{PO}_{4}$ in buffer A. RPA $(900 \mu \mathrm{g}$ total) eluted from hydroxyapatite at $\sim 55 \mathrm{mM} \mathrm{K \textrm {K } _ { 2 }} \mathrm{PO}_{4}$ and was concentrated to $1.5 \mathrm{mg} / \mathrm{ml}$ (Fraction IV) with a Centricon-30 concentrator and stored in small portions at $-70^{\circ} \mathrm{C}$.

\section{Immunoprecipitation}

Typically, 2 grams of frozen yeast paste was thawed in $6 \mathrm{ml}$ of buffer $150 \mathrm{~mm}$ Tris- $\mathrm{HCl}$ at $\mathrm{pH} 7.5,10 \%$ sucrose, $300 \mathrm{~mm} \mathrm{KCl}, 1.5$ mM EDTA, and 1 mM DTT) containing protease inhibitors, and extract was prepared with a French press (Sung 1987). The cell lysate was clarified by centrifugation $(100,000 \mathrm{~g}, 90 \mathrm{~min})$ and dialyzed against 1 liter of buffer $\mathrm{T}(20 \mathrm{~mm}$ Tris- $\mathrm{HCl}$ at $\mathrm{pH} 7.5$, $10 \%$ glycerol, $0.5 \mathrm{~mm}$ EDTA, and $0.5 \mathrm{~mm}$ DTT) containing 300 $\mathrm{mm} \mathrm{KCl}$ for $12 \mathrm{hr}$ on ice. The dialysate was clarified by centrifugation $(100,000 \mathrm{~g}$ for $90 \mathrm{~min})$, and $0.5 \mathrm{ml}$ of the supernatant was mixed gently at $4^{\circ} \mathrm{C}$ for $2 \mathrm{hr}$ with $7 \mu$ of protein $\mathrm{A}$-agarose beads containing covalently conjugated affinity purified antibodies (2 $\mathrm{mg} / \mathrm{ml}$ matrix) specific for Radl (Sung et al. 1993), Rad14 (Guzder et al. 1993), Rad55, and Rad57 (this work) proteins. The immunoprecipitates were washed twice with $300 \mu \mathrm{l}$ of ice-cold buffer $\mathrm{T}$ containing $300 \mathrm{mM} \mathrm{KCl}$, and then once with buffer $\mathrm{T}$, before being treated with $40 \mu \mathrm{l}$ of $2 \%$ SDS at $37^{\circ} \mathrm{C}$ for $10 \mathrm{~min}$ to elute bound proteins. Aliquots of the SDS eluates were analyzed by immunoblotting to reveal their content of Rad55 and Rad57 proteins.

\section{Examination of the strength of Rad55-Rad57 association}

Fraction VI Rad55-Rad57, $2 \mu \mathrm{g}$, was diluted to $300 \mu \mathrm{l}$ in buffer $\mathrm{T}$ containing $200 \mathrm{~mm} \mathrm{KCl}$ and bovine serum albumin at 200 $\mu \mathrm{g} / \mathrm{ml}$ and mixed gently with $15 \mu \mathrm{l}$ of protein A-agarose beads bearing covalently conjugated anti-Rad55 antibodies for $60 \mathrm{~min}$ at $4^{\circ} \mathrm{C}$ to immobolize the Rad55-Rad57 heterodimer via the Rad55 subunit. The beads containing the immunocomplex were washed with $500 \mu \mathrm{l}$ of ice-cold buffer $\mathrm{T}$, and then at room temperature with $30 \mu \mathrm{l}$ of $1 \mathrm{M} \mathrm{KCl}$ in buffer $\mathrm{T}$ for $30 \mathrm{sec}$, followed by $30 \mu 1$ of $0.05 \%, 0.1 \%, 0.2 \%, 0.3 \%, 0.5 \%$, and $1 \%$ SDS in buffer $\mathrm{T}$ at room temperature for $30 \mathrm{sec}$ each wash. Aliquots of the 1 $\mathrm{M} \mathrm{KCl}$ wash and all of the SDS washes were subjected to immunoblot analysis to determine their content of Rad55 and Rad57 proteins.

\section{Strand-exchange reactions}

In the experiment in Figure 5B, the reaction $(50 \mu \mathrm{l}$ of final volume) was assembled by mixing $14.5 \mu \mathrm{g}$ of $\operatorname{Rad} 51$ protein $(6.8 \mu \mathrm{M})$ added in $3 \mu$ of storage buffer with $2.4 \mu$ lof buffer $\mathrm{K}$ containing 250 mм KCl (used for storing the purified Rad55-Rad57 heterodimer) and $300 \mathrm{ng}$ of $\phi \mathrm{X} 174$ viral $|+|$ strand (18.4 $\mu \mathrm{M}$ nucleotides) added in $3 \mu$ of TE (10 mM Tris- $\mathrm{HCl}$ at $\mathrm{pH} 7.5,0.2 \mathrm{~mm}$ EDTA) in $40 \mu \mathrm{l}$ of buffer $\mathrm{R}$ ( $35 \mathrm{~mm}$ potassium MOPS at $\mathrm{pH} 7.2,25 \mathrm{~mm}$ $\mathrm{KCl}, 3 \mathrm{~mm}$ ATP, $3 \mathrm{~mm} \mathrm{MgCl} 2,1 \mathrm{~mm}$ DTT) and incubating at $37^{\circ} \mathrm{C}$ for $5 \mathrm{~min}$, followed by the addition of $4.5 \mu \mathrm{g} \mathrm{RPA}(0.76 \mu \mathrm{M})$ in $3 \mu$ lof storage buffer and a $5 \mathrm{~min}$ incubation at $37^{\circ} \mathrm{C}$, and then $300 \mathrm{ng}$ of $\phi X 174 \mathrm{dsDNA}(9.2 \mu \mathrm{M}$ base pairs) added in $3 \mu \mathrm{l}$ of TE and $4 \mu \mathrm{l}$ of $50 \mathrm{~mm}$ spermidine were incorporated. The addition of $\mathrm{mm}$ amounts of spermidine (Sung and Stratton 1996) or of $\mathrm{MgCl}_{2}$ (Sung 1994) to the reaction after incubation of ssDNA with the protein factors results in a higher level of pairing and strand exchange, with spermidine being more effective than $\mathrm{MgCl}_{2}$ in this regard. The complete reaction mixture was incubated at $37^{\circ} \mathrm{C}$, and $5.5 \mu \mathrm{l}$ portions were withdrawn at the indicated times and processed for agarose gel electrophoresis as described (Sung and Robberson 1995). DNA species were stained with ethidium bromide and photographed through a red filter with Polaroid type 55 films. The reaction that had no RPA (Fig. 5B) was assembled and incubated in exactly the same way, except that $3 \mu \mathrm{l}$ of storage buffer that did not contain RPA was added after preincubation of Rad5l protein with the viral $|+|$ strand.

Examination of effect of Rad55-Rad57 heterodimer on strand exchange

In the experiment described in Figure 5C, $14.5 \mu \mathrm{g}$ of Rad51 protein $(6.8 \mu \mathrm{M})$ added in $3 \mu \mathrm{l}$ of storage buffer, $4.5 \mu \mathrm{g}$ of RPA $(0.76 \mu \mathrm{M})$ added in $3 \mu \mathrm{l}$ of storage buffer, $2.4 \mu \mathrm{l}$ of buffer $\mathrm{K}$ with $250 \mathrm{mM} \mathrm{KCl}$ (used for storing the purified Rad55-Rad57 complex) and $300 \mathrm{ng}$ of $\phi \mathrm{X}$ viral $(+)$ strand (18.4 $\mu \mathrm{M}$ nucleotides) added in $3 \mu$ l of TE were mixed together in $40 \mu \mathrm{l}$ of buffer $\mathrm{R}$ on ice, and then incubated at $37^{\circ} \mathrm{C}$ for $10 \mathrm{~min}$, followed by the incorporation of $300 \mathrm{ng}$ of linear $\phi \mathrm{X}$ dsDNA (9.2 $\mu \mathrm{M} \mathrm{bp}$ ) added in $3 \mu \mathrm{l}$ of TE, $3 \mu \mathrm{l}$ of $\mathrm{H}_{2} \mathrm{O}$, and $4 \mu \mathrm{l}$ of $50 \mathrm{~mm}$ sperimidine to complete the reaction mixture $(50 \mu 1)$, which was incubated at $37^{\circ} \mathrm{C}$. At the times indicated, a $5.5 \mu$ portion was withdrawn and processed for agarose gel electrophoresis. To examine the effect of the purified Rad55-Rad57 heterodimer on strand exchange (Fig. 6), $14.5 \mu \mathrm{g}$ of $\operatorname{Rad} 51$ protein $(6.8 \mu \mathrm{M})$ in $3 \mu \mathrm{l}$ of storage buffer, $4.5 \mu \mathrm{g}$ of RPA $(0.76 \mu \mathrm{M})$ in $3 \mu \mathrm{l}$ of storage buffer, and $3.6 \mu \mathrm{g}$ of fraction VI Rad55-Rad57 heterodimer $(0.74 \mu \mathrm{M})$ in $2.4 \mu \mathrm{l}$ of storage buffer were mixed with $300 \mathrm{ng}$ of $\phi \mathrm{X}$ viral $|+|$ strand (18.4 $\mu \mathrm{M}$ nucleotides) added in $3 \mu \mathrm{l}$ of TE in $40 \mu \mathrm{l}$ of buffer $\mathrm{R}$ on ice and then incubated at $37^{\circ} \mathrm{C}$ for $10 \mathrm{~min}$, followed by the incorporation of $300 \mathrm{ng}$ of linear $\phi \mathrm{X}$ dsDNA $(9.2 \mu \mathrm{M} \mathrm{bp})$ in $3 \mu \mathrm{l}$ of $\mathrm{TE}, 3 \mu \mathrm{l}$ of $\mathrm{H}_{2} \mathrm{O}$, and $4 \mu \mathrm{l}$ of $50 \mathrm{~mm}$ sperimidine to complete the reaction mixture $(50 \mu \mathrm{l})$, which was incubated at $37^{\circ} \mathrm{C}$. Portions $(5.5 \mu l)$ of the reaction mixture were withdrawn at the indicated times and processed for agarose gel electrophoresis.

\section{Densitometry}

Image analyses were done in a Bio-Rad GS670 imaging densitometer.

\section{Acknowledgments}

I am very grateful to Louise Prakash and Satya Prakash for discussions, and to Sabrina Stratton for technical assistance and help in artwork. This work was supported by PHS grant R01 ES07061 from the National Institute of Environmental Health Sciences.

The publication costs of this article were defrayed in part by payment of page charges. This article must therefore be hereby marked "advertisement" in accordance with 18 USC section 1734 solely to indicate this fact.

\section{References}

Brill, S.J. and B. Stillman. 1989. Yeast replication factor-A functions in the unwinding of the SV40 origin of DNA replication. Nature 342: 92-95.

Cao, L., E. Alani, and N. Kleckner. 1990. A pathway for generation and processing of double-strand breaks during meiotic recombination in S. cerevisiae. Cell 61: 1089-1101.

Cox, M.M., and I.R. Lehman. 1987. Enzymes of General Recombination. Annu. Rev. Biochem. 56: 229-262.

Guzder, S.N., P. Sung, L. Prakash, and S. Prakash. 1993. Yeast DNA repair gene RAD14 encodes a zine metalloprotein with affinity for ultraviolet damaged DNA. Proc. Nat1. Acad. Sci. 90: $5433-5437$. 
Hays, S.L., A.A. Firmenich, and P. Berg. 1995. Complex formation in yeast double-strand break repair: Participation of Rad51, Rad52, Rad55, and Rad57 proteins. Proc. Natl. Acad. Sci. 92: 6925-6929.

Henricksen, L.A., C.B. Umbricht, and M.S. Wold. 1994. Recombinant replication protein A: Expression, complex formation, and functional characterization. J. Biol. Chem. 269: 24203-24208.

Johnson, R.D. and L.S. Symington. 1995. Functional differences and interactions among the putative RecA homologs Rad51, Rad55, and Rad57. Mol. Cell. Biol. 15: 4843-4850.

Kans, J.A. and R.K. Mortimer. 1991. Nucleotide sequence of the RAD57 gene of Saccharomyces cerevisiae. Gene 105: 139140.

Kingsman, S.M., D. Covsens, C.A. Stanway, A. Chambers, M. Wilson, and A.J. Kingsman. 1990. High efficiency yeast expression vectors based on the promoter of the phosphoglycerate kinase gene. Methods Enzymol. 185: 329-341.

Kowalczykowski, S.C., D.A. Dixon, A.K. Eggleston, S.D. Lauder, and W.M. Rehrauer. 1994. Biochemistry of homologous recombination in E. coli. Microbiol. Rev. 58: 401-465.

Lovett, S.T. 1994. Sequence of the RAD55 gene of Saccharomyces cerevisiae: Similarity of RAD55 to prokaryotic RecA and other RecA like proteins. Gene 142: 103-106.

Lovett, S.T. and R.K. Mortimer. 1987. Characterization of null mutants of the RAD55 gene of Saccharomyces cerevisiae: Effects of temperature, osmotic strength, and mating type. Genetics 116: 547-553.

Ogawa, T., X. Yu, A. Shinohara, and E.H. Egelman. 1993. Similarity of the yeast RAD51 filament to the bacterial RecA filament. Science 259: 1896-1899.

Petes, T.D., R.E. Malone, and L.S. Symington. 1991. Recombination in yeast. In The molecular and cellular biology of the yeast Saccharomyces: Genome dynamics, protein synthesis, and energetics (ed. J.R. Broach, E.W. Jones, and J.R. Pringle), pp. 407-521. Cold Spring Harbor Laboratory Press, Cold Spring Harbor, NY.

Radding, C.M. 1991. Helical interactions in homologous pairing and strand exchange driven by RecA protein. J. Biol. Chem. 266: 5355-5358.

Ratray, A.J. and L.S. Symington. 1995. Multiple pathways for homologous recombination in Saccharomyces cerevisiae. Genetics 139: 45-56.

Reynolds, P., L. Prakash, and S. Prakash. 1987. Nucleotide sequence and functional analysis of the RAD1 gene of Saccharomyces cerevisiae. Mol. Cell. Biol. 7: 1012-1020.

Shinohara, A., H. Ogawa, and T. Ogawa. 1992. Rad51 protein involved in repair and recombination in $S$. cerevisiae is a RecA-like protein. Cell 69: 457-470.

Sugawara, N., E.L. Ivanov, J. Fishman-Lobell, B.L. Ray, X. Wu, and J.E. Haber. 1995. DNA structure-dependent requirements for yeast $R A D$ genes in gene conversion. Nature 373: 84-86.

Sun, H., D. Treco, and J.W. Szostak. 1991. Extensive 3'-overhanging, single-stranded DNA associated with the meiosisspecific double-strand breaks at the ARG4 recombination initiation site. Cell 64: 1155-1161.

Sung, P. 1994. Catalysis of ATP dependent homologous DNA pairing and strand exchange by yeast Rad51 protein. Science 265: $1241-1243$.

Sung, P. and D.L. Robberson. 1995. DNA strand exchange mediated by a Rad51-ssDNA nucleoprotein filament with polarity opposite to that of RecA. Cell 82: 453-461.

Sung, P. and S.A. Stratton. 1996. Yeast Rad51 recombinase mediates polar DNA strand exchange in the absence of ATP hydrolysis. J. Biol. Chem. 271: 27983-27986.
Sung, P., L. Prakash, S.W. Matson, and S. Prakash. 1987. Rad3 protein of Saccharomyces cerevisiae is a DNA helicase. Proc. Natl. Acad. Sci. 84: 6045-6049.

Sung, P., P. Reynolds, L. Prakash, and S. Prakash. 1993. Purification and characterization of the Saccharomyces cerevisaie Radl/Rad10 endonuclease. I. Biol. Chem. 268: 2639126399.

Szostak, J.W., T.L. Orr-Weaver, and R.J. Rothstein. 1983. The double-strand-break repair model for recombination. Cell 33: $25-35$.

Umezu, K., N.W. Chi, and R.D. Kolodner. 1993. Biochemical interaction of the Escherichia coli RecF, RecO, and RecR proteins with RecA protein and single-stranded DNA binding protein. Proc. Nat1. Acad. Sci. 90: 3875-3879. 


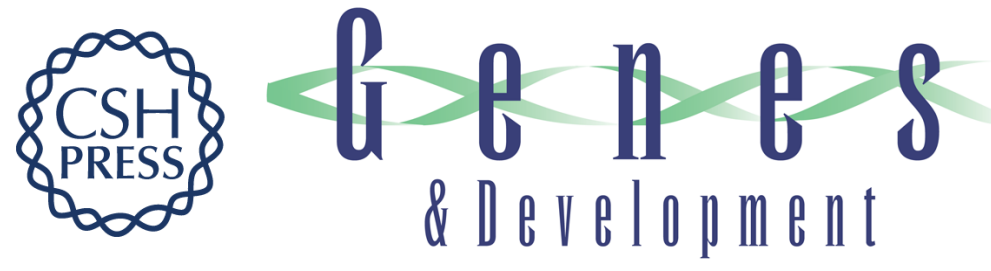

\section{Yeast Rad55 and Rad57 proteins form a heterodimer that functions with replication protein A to promote DNA strand exchange by Rad51 recombinase.}

P Sung

Genes Dev. 1997, 11:

Access the most recent version at doi:10.1101/gad.11.9.1111

References This article cites 26 articles, 14 of which can be accessed free at:

http://genesdev.cshlp.org/content/11/9/1111.full.html\#ref-list-1

License

Email Alerting Service

Receive free email alerts when new articles cite this article - sign up in the box at the top right corner of the article or click here.

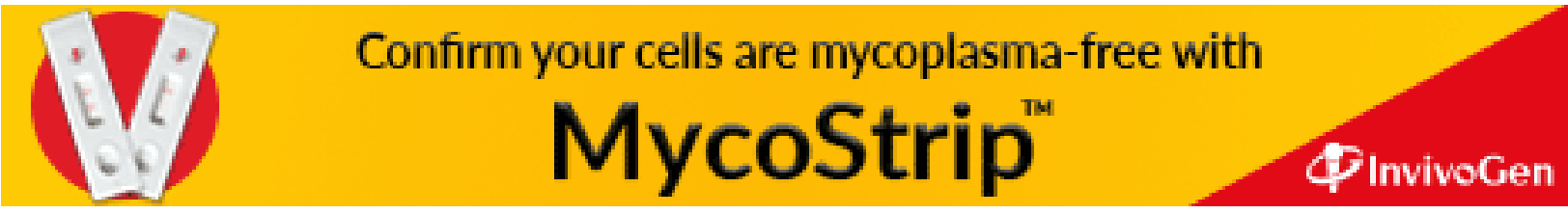

